\title{
THE EAST CAPE EXPERIENCE
}

M. J. FITZHARRIS

Farm Advisory Officer, MAF, Gisborne

Abstract

It will be recalled that the East Cape Project incorporating Poverty Bay/East Coast areas was titled "Wise Land Use and Community Development", and that the main objectives of the project were social ones; stabilizing communities by providing employment, and building up farmer confidence through stabilization of the soils by afforestation.

In the first instance, the study looked at the land's suitability for use for farming, since this was the greater part of the region. The proposed categories and their recommended policies are:-

Category 1 Land with a long term future in farming and requiring no erosion control work, or only moderate remedial and preventative erosion control treatment.

Policy Every encouragement should be given to maintain this land i n f a r m in g.

Category 2 Land with a long term future in pastoral farming only if intensive erosion control practices are carried out.

Policy Encourage farming with appropriate programmes of erosion control which may involve areas of afforestation.

Category 3 Land with some future for pastoral farming but predominantly more suitable for afforestation.

Policy Encourage forest use of this land.

Category 4 Land with no potential for primary production.

Policy Encourage protective bush.

The programme saw the control of erosion as bringing back a measure of confidence to the area. This would -

$\star$ Speed up horticultural development on the flats.

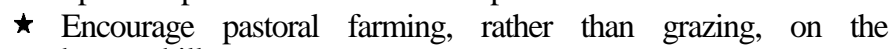
better hills.

$\star$ Bring about forest development with associated industries.

• Underpin the local economy, attract people back, and slow down or stop the excessive drift of young people away.

After a decade it's interesting to review the project, and have some ideas of the social and environmental consequences of the alternatives proposed.

At the onset, policy makers had to be made more aware that subsidies and 
incentives designed for the average pastoral producer in New Zealand fell short of the region's requirements. Yet many of those average New Zealand pastoral producers rely on the region's continued output. This was critical, for the competition for labour, with forestry type occupations and horticulture, coupled with the continued urban drift, plus the existence of the generous unemployment benefits, made farm labour expensive or unprocurable. Escalating building costs for employee housing, ever increasing boarding school fees, the high cost of car replacement and running, are other factors contributing to the distribution of the East Coast's earning potential, far outside of the region.

The direct employment of all persons associated with establishing the target of 6,000 ha forest annually, puts enormous pressures on the farming community, usually initially to their detriment. Indirect or spin offeffects that this direct employment generates, includes such things as an expanding demand for retailing, health, education, government services, and an increased demand for the supply of materials and construction services.

I've been told that in our area the average person employed has a wife, and 2-3 children. And for every two such families, you need another one to service them. Direct and indirect employment then, associated with our new forestry and horticulture industries could build up to 12,000 odd people with 2-3000 in the first ten years, this could have a population impact of 15-20,000, with 3,400 of these in the first ten years. All with a non-emphasis or little interest in pastoral farming. This also implies a certain redistribution of the labour force.

Forestry and horticulture then initially direct labour away from farming and it is now well know that forestry can hold this labour through its comparatively higher wages, and possibly more regular work. Furthermore, the normal lack of jobs for women, is offset by the horticultural development, so family incomes are further enhanced, to the detriment of pastoral farming. With the increasing scale of horticulture and afforestation, there appears to be less population scattered in the rural areas. Consequently, the need to recognise some services to rural areas. So the feeling of resentment. As well there is the reduced regional income from pastoral farming, with reduced demand for processing, handling, and servicing industries associated with farming. The key to saving our services locally, was the encouragement of much of the land outside the forested area, to take the load from the areas going into forest. The regions total livestock numbers consequently have not fallen.

Another factor now showing up, is that, after the initial accentuated labour problems, with an increasing or more stable population, farm labour is now becoming more readily available. This it appears though, may be only after half a generation, say 15-20 years.

So much depends on how sensitive the implementation of horticultural and forestry projects are to the social needs of the existing and immigrant population. From our experience, there needs to be measures to ensure that the present people are not isolated with poor services, at the expense of 
keeping the new developing visual programme that is obvious to everyone. The acceptability of the social and environmental impacts of the alternative schemes need to be worked out within the region, and the objectives of the region need to be actively sought and expressed, and weighed up against each alternative. 